Egyptian Journal of Aquatic Biology \& Fisheries

Zoology Department, Faculty of Science,

Ain Shams University, Cairo, Egypt.

ISSN $1110-6131$

Vol. 24(7): 803 - 816 (2020)

www.ejabf.journals.ekb.eg

\title{
Farmed Versus Wild Fish Consumption in Relation to Fatty Acid Composition in Kingdom of Bahrain
}

\author{
Sarah, Al-Asheeri *, Afnan, Freije and Simone, Perna \\ Department of Biology, College of Science, University of Bahrain, Sakhir Campus, \\ Kingdom of Bahrain \\ *Corresponding Author: $\underline{\text { s.alasheeri@ outlook.com }}$
}

\begin{abstract}
ARTICLE INFO
Article History:

Received: Sept. 29, 2020

Accepted: Nov. 30, 2020

Online: Dec.30,2020
\end{abstract}

Keywords:

Farmed fish,

Wild fish,

Fatty acid,

Bahrain.

\section{INTRODUCTION}

\section{The benefits of fish consumption depend on the amount of} polyunsaturated fatty acids (PUFAs), especially eicosapentaenoic acid (EPA; C20:5 n3) and ocosahexaenoic acid (DHA; C22:6 n3) in the portion of fish consumed. This study was performed to compare some farmed (local and imported) fish species and some of the most consumed wild fish species in Bahrain markets in terms of n-3 (omega-3) and n-6 (omega-6) PUFAs, n3/n-6 ratio and EPA and DHA values. Lipid was extracted with a mixture of methanol: chloroform $(1: 1 \mathrm{v} / \mathrm{v})$. It was converted into fatty acid methyl esters (FAMEs) through the fatty acid methylation process, and then analysed through gas chromatography (GC-FID). The results showed that there were no significant differences $(\mathrm{P}>0.05)$ between wild and farmed fish in total n-3 PUFAs, but farmed fish was significantly higher than the wild $(\mathrm{P}<0.05)$ in total $\mathrm{n}-6$ PUFAs concentration. Wild fish had significantly higher EPA and marginally higher DHA compared to farmed fish. The n3/n-6 ratio was significantly higher $(\mathrm{P}<0.05)$ in wild fish compared to farmed fish. This study concluded that all the selected fish samples (wild and farmed) contain higher ratios of n-3/n-6 than the suggested optimal ratio (0.2). However, all wild sampled fishes (except for Greasy Grouper) included in the study, were potentially healthier for consumers as part of a regular well-balanced diet. Among wild fish samples, the top three richest fish in n-3 PUFAs that can be the favourite consumer's choice at the Kingdom of Bahrain for health promoting are Doublebar Bream (Faskar), Spangled Emperor (Sha'ree), and Rabbitfish (Saffy). In contrast, the deficit in n-3 PUFAs content of farmed fish accounted for the reduction in their nutritional quality that may have resulted from poorly manufactured feed.

Fish protein contains all the essential amino acids and it is an indispensable dietary source of some vital minerals like iodine, selenium, iron, zinc and some vitamins like vitamin B, A, D and E (Onyia et al., 2013; Tocher, 2015). However, fish uniqueness is mainly because of the large amounts of lipids that accumulate in its muscles, liver and other tissues. The accumulated lipids are mainly three polyunsaturated fatty acids (PUFAs): eicosapentaenoic acid (EPA), docosahexaenoic acid (DHA), and arachidonic 
acid (AA). PUFAs can be classified according to the position of the double bonds to $n-3$ (omega-3) and n-6 (omega-6) families (Usydus et al., 2011). EPA and DHA belong to n-3 family of fatty acids which are well-known and scientifically accepted benefitial effects on human health including; preventive effects on cardiovascular diseases (CVD), coronary heart diseases (CHD), inflammatory and autoimmune disorders, and cancers with an important role in nervous system (brain), photoreception system (vision), and reproductive system development (Simopoulos, 2006; Freije, 2009; Hossain, 2011; Usydus et al., 2011; Tocher, 2015; Amoussou et al., 2019). Further health benefits of n3 PUFAs also depends on the n-3/n-6 ratio and factors affecting n-3 PUFAs amount (Hossain, 2011; Usydus et al., 2011).

Notedly, in the resource base fish stock is continuously shrinking while the human population and demand for fish are increasing. Thus, farmed fish are now being offered to consumers as an alternative and there was and still expectation that the gap can be filled with aquaculture sector as reported by the Food and Agriculture Organization of the United Nation (FAO) in 2008 (Hossain, 2011). Fish farming is referred to the technique that is used for raising fish in tanks or ponds with providing inputs such as energy source, water, and land (FAO, 2012; Campbell and Pauly, 2013). In the Kingdom of Bahrain, it has been planned to develope the aquaculture sector for food security and self-sufficiency (FAO, 2015). Currently, there are limited commercial maricultural projects in operation in Bahrain and the National Mariculture Centre (NMC) activities are limited to applied research (FAO, 2015).

This study was conducted in order to compare between some farmed (local and imported) fish species and the most consumed wild fish species in Bahrain markets in terms of n-3 and n-6 PUFAs, n-3/n-6 ratio, and EPA and DHA values. In addition, this study aimed to determine whether wild fish were the better dietary option for consumers compared to farmed fish; discussing benefits and risk factors associated with farmed fish consumption in comparison to wild fish consumption.

\section{MATERIALS AND METHODS}

\section{Sample preparation}

A total of 8 fish species (Rabbitfish, Spangled Emperor, Greasy Grouper, Spanish Mackerel, Doublebar Bream, Sobaity Seabream, Seabass, and Gilthead Seabream) were selected from the most commonly consumed and available at the Kingdom of Bahrain markets, while others were farmed in Bahrain and/or other countries (Table 1). Wild and imported farmed fish samples were purchased separately and freshly from the local central fish markets and other large supermarkets in Bahrain during January-June 2019. After collection, fish samples were placed in an ice box and transported freshly to the laboratory. Fish length $(\mathrm{cm})$ and weight $(\mathrm{g})$ were measured to the nearest \pm 0.1 millimetre and milligram (Table 1). Fish samples were washed with distilled water and then dissected. The two sides fish fillets were homogenized in a blender and prepared for 
immediate further analysis. Five specimens were provided from each fish sample, and two replicas from each specimen were prepared.

Table 1: The local, common and scientific names, type (wild /farmed), the source, number of samples, the length $(\mathrm{cm})$, the weight $(\mathrm{g})$ and the date of collection of fish samples that were included in the study.

\begin{tabular}{|c|c|c|c|c|c|c|c|c|}
\hline $\begin{array}{l}\text { Local } \\
\text { name }\end{array}$ & $\begin{array}{l}\text { Common } \\
\text { name }\end{array}$ & Scientific name & Type & Source & $\begin{array}{c}\text { No. of } \\
\text { samples }\end{array}$ & $\begin{array}{c}\text { Net } \\
\text { length } \\
(\mathrm{cm})\end{array}$ & $\begin{array}{c}\text { Net } \\
\text { weight } \\
\text { (g) }\end{array}$ & $\begin{array}{c}\text { Date of } \\
\text { sample } \\
\text { collection }\end{array}$ \\
\hline Saffy & Rabbitfish & $\begin{array}{c}\text { Siganus } \\
\text { canaliculatus }\end{array}$ & Wild & $\begin{array}{l}\text { Local, } \\
\text { Bahrain }\end{array}$ & 5 & 24.8 & 248 & Jan 2019 \\
\hline Sha'ree & $\begin{array}{l}\text { Spangled } \\
\text { Emperor }\end{array}$ & $\begin{array}{l}\text { Lethrinus } \\
\text { nebulosus }\end{array}$ & Wild & $\begin{array}{l}\text { Local, } \\
\text { Bahrain }\end{array}$ & 5 & 28.6 & 268.2 & Jan 2019 \\
\hline Hamoor & $\begin{array}{l}\text { Greasy } \\
\text { Grouper }\end{array}$ & $\begin{array}{l}\text { Epinephelus } \\
\text { coioides }\end{array}$ & Wild & $\begin{array}{l}\text { Local, } \\
\text { Bahrain }\end{array}$ & 5 & 26.8 & 340 & July 2019 \\
\hline Chana'ad & $\begin{array}{c}\text { Spanish } \\
\text { Mackerel }\end{array}$ & $\begin{array}{l}\text { Scombermorous } \\
\text { commerson }\end{array}$ & Wild & $\begin{array}{l}\text { Local, } \\
\text { Bahrain }\end{array}$ & 5 & 113 & 1161 & June 2019 \\
\hline Faskar & $\begin{array}{l}\text { Doublebar } \\
\text { Bream }\end{array}$ & $\begin{array}{c}\text { Acanthopagrus } \\
\text { bifaciatus }\end{array}$ & Wild & $\begin{array}{l}\text { Local, } \\
\text { Bahrain }\end{array}$ & 5 & 28.2 & 446 & Feb 2019 \\
\hline Sobaity & $\begin{array}{l}\text { Sobaity } \\
\text { Seabream }\end{array}$ & $\begin{array}{l}\text { Sparidentex } \\
\text { hasta }\end{array}$ & Wild & $\begin{array}{l}\text { Local, } \\
\text { Bahrain }\end{array}$ & 5 & 38.5 & 710 & March 2019 \\
\hline Seabream & $\begin{array}{l}\text { Gilthead } \\
\text { Seabream }\end{array}$ & Sparus aurata & Farmed & $\begin{array}{l}\text { NMC, } \\
\text { Bahrain }\end{array}$ & 5 & 37.35 & 335.45 & April 2019 \\
\hline Sobaity & $\begin{array}{l}\text { Sobaity } \\
\text { Seabream }\end{array}$ & $\begin{array}{l}\text { Sparidentex } \\
\text { hasta }\end{array}$ & Farmed & $\begin{array}{l}\text { NMC, } \\
\text { Bahrain }\end{array}$ & 5 & 22.2 & 149.2 & April 2019 \\
\hline Seabass & Seabass & $\begin{array}{l}\text { Dicentrarchus } \\
\text { labrax }\end{array}$ & Farmed & $\begin{array}{l}\text { Imported, } \\
\text { France }\end{array}$ & 5 & 34 & 467.6 & March 2019 \\
\hline Seabream & $\begin{array}{l}\text { Gilthead } \\
\text { Seabream }\end{array}$ & Sparus aurata & Farmed & $\begin{array}{l}\text { Imported, } \\
\text { UAE }\end{array}$ & 5 & 30.6 & 523.6 & March 2019 \\
\hline
\end{tabular}

\section{Lipid extraction}

Lipid was extracted with a mixture of methanol: chloroform $(1: 1 \mathrm{v} / \mathrm{v})$ following the procedures of Bligh and Dyer (1959) extraction method with some modifications as described by Freije and Awadh (2009). First, raw fish muscle was grinded, and one gram was transferred into a large Pyrex reaction tube and homogenized with $6 \mathrm{ml}$ of saline solution $(0.85 \%)$. The homogenate was extracted by adding $15 \mathrm{ml}$ methanol, $7.5 \mathrm{ml}$ chloroform twice, and $10 \mathrm{ml}$ of water was shaken vigorous for 30 seconds after each addition using whirl mixer. The mixture was centrifuged for $10 \mathrm{~min}$ at $2500 \mathrm{rpm}$ and then filtered for discarding the muscle plug. The filtrate was transferred to a test tube and was allowed to separate into two layers. The top layer was removed, and the lower layer that contained the lipid extract in chloroform was transferred to another pre-weighted test tube. The chloroform layer was evaporated to dryness using nitrogen gas, and then the test tube was weighed again for determining the total lipid content.

\section{Fatty acid methylation}

Fatty acid methylation process was applied following the procedures of AOAC (1990) with some modifications as described by Ozogul et al. (2012). Twenty-five milligrams (25 microliter) of extracted fish oil were transferred into a test tube, 
to which $1.5 \mathrm{ml}$ of $0.5 \mathrm{M}$ methanolic sodium hydroxide was added, mixed, heated at $100^{\circ} \mathrm{C}$ for $7 \mathrm{~min}$ and then cooled at room temperature. Two millilitres of $14 \%$ Borontrifloride-methanol were added; the mixture was heated again at $100^{\circ} \mathrm{C}$ for $5 \mathrm{~min}$ and then cooled to $30-40^{\circ} \mathrm{C}$. One millilitre of isooctane was added, and the tube was shaken for 30 seconds using whirl mixer. Five millilitres of saturated sodium chloride were added immediately, and the tube was shaken again for 30 seconds. The contents were allowed to separate and the upper isooctane containing fatty acid methyl esters (FAMEs) was removed and placed into another test tube. The lower layer was extracted again with an additional $1.0 \mathrm{ml}$ of isooctane and was shaken for 30 seconds. The two isooctane extracts were combined, dried over tiny amount of anhydrous sodium sulphate, concentrated to $1.0 \mathrm{ml}$ under nitrogen gas and frozen at $-20^{\circ} \mathrm{C}$ until analysis.

\section{Fatty acid analysis}

The fatty acid analysis was performed using Perkin Elmer, Clarus 500 GC-FID equipped with Flam Ionization Detector (FID) and Thermal Conductivity Detector (TCD). The individual FAMEs were separated using a fused carbon-silica column (Stabilwax, Crossbond, Carbowax, Polyethylene glycol) with $30 \mathrm{~m}$ length, $0.25 \mathrm{~mm}$ of internal diameter (width), $0.25 \mu \mathrm{m}$ film thickness and a temperature range of $40^{\circ} \mathrm{C}$ to $260^{\circ} \mathrm{C}$. The oven temperature was set at $200^{\circ} \mathrm{C}$ and held constant for 80 minutes (the total run time for each sample). The FID temperature was set at $300^{\circ} \mathrm{C}$ and TCD temperature was set at $150^{\circ} \mathrm{C}$. The injector temperature was maintained at $250^{\circ} \mathrm{C}$ with a split ratio of 1:20. Nitrogen gas was used as a carrier gas at flow rate $0.76 \mathrm{ml} / \mathrm{min}$ and the other two gases were air with a flow rate of $450 \mathrm{ml} / \mathrm{min}$ and hydrogen with a flow rate of 45 $\mathrm{ml} / \mathrm{min}$. The sample injected volume was $5 \mu \mathrm{l}$ with 3 pre- and post- injection sample washes. A sampling rate of $12.5 \mathrm{~Hz}$ was used. The FAMEs were identified based on the authentic standards (PUFA No.1 and PUFA No.2) supplied by SUPELCO USA.

\section{Data analysis}

All analysis was carried out using Statistical Package for Social Science (SPSS) version 24 and statistical package from Excel 2017 (Microsoft Office). Descriptive analysis, two-way ANOVA, Pairwise comparisons and Post-hoc analysis was performed using Least Square Difference method and significance was set at 0.05.

\section{RESULTS AND DISCUSSION}

\section{Saturated fatty acids (SFAs)}

The percentage of SFAs in wild and farmed fish as shown in Table 2 was characterized by high level in comparison to other studies on other fish species (Alasalvar et al., 2002; Mnari et al., 2007; Fuentes et al., 2010; Usydus et al., 2011; O'Neill et al., 2015). SFAs are used for energy production in some fish species and its high level may result from lipogenic activity (Amoussou et al., 2019). 
Table 2: Total lipid and fatty acids composition of farmed and wild fish species.

\begin{tabular}{|c|c|c|c|c|c|c|c|c|c|c|}
\hline $\begin{array}{c}\text { FISH } \\
\text { NAME }\end{array}$ & $\begin{array}{c}\text { Gilthead } \\
\text { Seabream } \\
\text { (Imported) }\end{array}$ & $\begin{array}{c}\text { Gilthead } \\
\text { Seabream } \\
\text { (NMC) }\end{array}$ & $\begin{array}{c}\text { Seabass } \\
\text { (Imported) }\end{array}$ & $\begin{array}{c}\text { Sobaity } \\
\text { Seabream } \\
\text { (NMC) }\end{array}$ & $\begin{array}{c}\text { Doublebar } \\
\text { Bream }\end{array}$ & $\begin{array}{c}\text { Greasy } \\
\text { Grouper }\end{array}$ & Rabbitfish & $\begin{array}{c}\text { Sobaity } \\
\text { Seabream }\end{array}$ & $\begin{array}{l}\text { Spangled } \\
\text { Emperor }\end{array}$ & $\begin{array}{l}\text { Spanish } \\
\text { Mackerel }\end{array}$ \\
\hline $\begin{array}{c}\text { Total Lipid } \\
(\mathrm{g} / \mathrm{g})\end{array}$ & $0.23 \pm 0.03$ & $0.16 \pm 0.03$ & $0.28 \pm 0.04$ & $0.13 \pm 0.03$ & $0.30 \pm 0.07$ & $0.19 \pm 0.03$ & $0.13 \pm 0.08$ & $0.11 \pm 0.02$ & $0.21 \pm 0.05$ & $0.16 \pm 0.02$ \\
\hline \multicolumn{11}{|l|}{$\begin{array}{c}\text { Fatty acids } \\
(\%)\end{array}$} \\
\hline SFAs & $16.43 \pm 0.92$ & $24.91 \pm 0.73$ & $16.46 \pm 1.17$ & $30.31 \pm 0.64$ & $24.76 \pm 2.44$ & $30.02 \pm 0.68$ & $26.42 \pm 0.73$ & $26.02 \pm 0.48$ & $26.77 \pm 1.00$ & $27.07 \pm 0.53$ \\
\hline C16:0 & $2.33 \pm 0.26$ & $4.19 \pm 0.26$ & $2.17 \pm 0.34$ & $3.58 \pm 0.36$ & $1.31 \pm 0.31$ & $3.59 \pm 0.79$ & $2.72 \pm 0.24$ & $2.87 \pm 0.21$ & $2.33 \pm 0.57$ & $1.87 \pm 0.19$ \\
\hline C18:0 & $14.10 \pm 0.70$ & $20.73 \pm 0.56$ & $14.29 \pm 0.86$ & $26.42 \pm 0.56$ & $23.45 \pm 2.23$ & $26.43 \pm 0.75$ & $23.70 \pm 0.73$ & $23.15 \pm 0.38$ & $24.44 \pm 0.96$ & $25.20 \pm 0.38$ \\
\hline UFAs & $75.67 \pm 1.37$ & $65.49 \pm 0.83$ & $76.99 \pm 1.22$ & $60.89 \pm 1.45$ & $58.96 \pm 1.39$ & $53.65 \pm 1.54$ & $57.69 \pm 2.59$ & $48.62 \pm 1.54$ & $59.76 \pm 1.57$ & $58.21 \pm 0.89$ \\
\hline MUFAs & $12.06 \pm 0.38$ & $16.83 \pm 0.24$ & $12.68 \pm 0.44$ & $15.29 \pm 0.89$ & $15.80 \pm 0.72$ & $20.42 \pm 0.75$ & $16.56 \pm 1.23$ & $14.53 \pm 0.77$ & $14.22 \pm 1.34$ & $16.92 \pm 0.42$ \\
\hline C16:1 n7 & $5.14 \pm 0.41$ & $8.22 \pm 0.26$ & $3.76 \pm 0.34$ & $6.31 \pm 0.50$ & $2.64 \pm 0.68$ & $7.37 \pm 0.46$ & $5.69 \pm 0.96$ & $4.01 \pm 0.27$ & $3.14 \pm 0.93$ & $3.67 \pm 0.33$ \\
\hline C18:1 n9 & $3.25 \pm 0.27$ & $4.12 \pm 0.17$ & $3.33 \pm 0.12$ & $5.62 \pm 0.70$ & $9.92 \pm 0.58$ & $9.37 \pm 0.56$ & $8.04 \pm 0.55$ & $7.35 \pm 0.48$ & $7.83 \pm 0.51$ & $11.03 \pm 0.35$ \\
\hline C20:1 n9 & $2.36 \pm 0.25$ & $0.62 \pm 0.03$ & $2.50 \pm 0.22$ & $0.58 \pm 0.02$ & $0.51 \pm 0.11$ & $0.86 \pm 0.04$ & $0.48 \pm 0.10$ & $0.97 \pm 0.04$ & $0.36 \pm 0.13$ & $0.58 \pm 0.04$ \\
\hline C22:1 n11 & $1.31 \pm 0.16$ & $3.86 \pm 0.20$ & $3.08 \pm 0.49$ & $2.74 \pm 0.17$ & $2.73 \pm 0.52$ & $2.82 \pm 0.86$ & $2.35 \pm 0.92$ & $2.02 \pm 0.40$ & $2.90 \pm 0.64$ & $1.64 \pm 0.14$ \\
\hline PUFAs & $63.61 \pm 1.14$ & $48.66 \pm 0.99$ & $64.31 \pm 1.28$ & $45.60 \pm 0.91$ & $43.16 \pm 1.23$ & $33.22 \pm 1.21$ & $41.13 \pm 2.13$ & $34.09 \pm 0.98$ & $45.54 \pm 2.40$ & $41.28 \pm 0.51$ \\
\hline$n-6$ & $34.26 \pm 0.67$ & $27.49 \pm 0.82$ & $35.31 \pm 0.85$ & $28.77 \pm 0.65$ & $11.99 \pm 0.90$ & $17.38 \pm 0.86$ & $14.86 \pm 0.81$ & $14.59 \pm 0.38$ & $15.97 \pm 0.65$ & $20.20 \pm 0.69$ \\
\hline C18:2 n6 & $31.56 \pm 0.65$ & $23.97 \pm 0.82$ & $32.46 \pm 0.81$ & $25.91 \pm 0.46$ & $8.51 \pm 0.82$ & $12.55 \pm 0.49$ & $9.70 \pm 0.58$ & $11.24 \pm 0.31$ & $12.05 \pm 0.59$ & $16.26 \pm 0.24$ \\
\hline C18:3 n6 & $2.54 \pm 0.09$ & $3.20 \pm 0.07$ & $2.71 \pm 0.08$ & $2.63 \pm 0.11$ & $2.04 \pm 0.21$ & $3.22 \pm 0.29$ & $2.98 \pm 0.68$ & $2.83 \pm 0.26$ & $2.27 \pm 0.36$ & $3.34 \pm 0.24$ \\
\hline C22:4 n6 & $0.17 \pm 0.03$ & $0.32 \pm 0.04$ & $0.13 \pm 0.01$ & $0.22 \pm 0.22$ & $1.43 \pm 0.34$ & $1.61 \pm 0.33$ & $2.18 \pm 0.45$ & $0.52 \pm 0.07$ & $1.65 \pm 0.28$ & $0.61 \pm 0.02$ \\
\hline$n-3$ & $29.35 \pm 1.15$ & $21.17 \pm 0.90$ & $29.00 \pm 0.62$ & $16.84 \pm 0.50$ & $31.17 \pm 1.51$ & $15.84 \pm 0.72$ & $26.27 \pm 2.10$ & $19.50 \pm 0.91$ & $29.57 \pm 2.68$ & $21.08 \pm 0.46$ \\
\hline C18:3 n3 & $17.81 \pm 0.45$ & $11.12 \pm 0.23$ & $17.90 \pm 0.57$ & $9.33 \pm 0.43$ & $2.04 \pm 0.46$ & $1.35 \pm 0.17$ & $2.42 \pm 0.66$ & $2.15 \pm 0.36$ & $2.58 \pm 0.93$ & $2.03 \pm 0.35$ \\
\hline C18:4 n3 & $2.06 \pm 0.10$ & $0.79 \pm 0.04$ & $3.46 \pm 0.12$ & $0.50 \pm 0.04$ & $0.28 \pm 0.06$ & $0.39 \pm 0.04$ & $0.32 \pm 0.04$ & $0.64 \pm 0.04$ & $0.71 \pm 0.19$ & $0.34 \pm 0.05$ \\
\hline $\begin{array}{l}\text { C20:5 n3 } \\
\text { (EPA) }\end{array}$ & $2.22 \pm 0.18$ & $1.08 \pm 0.12$ & $0.99 \pm 0.10$ & $0.71 \pm 0.10$ & $7.66 \pm 0.81$ & $4.20 \pm 0.64$ & $6.38 \pm 0.82$ & $8.06 \pm 0.39$ & $9.71 \pm 0.91$ & $3.76 \pm 0.29$ \\
\hline $\begin{array}{l}\text { C22:6 n3 } \\
\text { (DHA) }\end{array}$ & $5.63 \pm 0.74$ & $6.20 \pm 0.64$ & $5.15 \pm 0.40$ & $5.08 \pm 0.49$ & $18.97 \pm 0.71$ & $8.04 \pm 0.52$ & $13.00 \pm 0.61$ & $7.08 \pm 0.23$ & $14.60 \pm 0.92$ & $13.06 \pm 0.31$ \\
\hline C22:5 n3 & $1.63 \pm 0.20$ & $1.99 \pm 0.17$ & $1.49 \pm 0.38$ & $1.20 \pm 0.23$ & $2.22 \pm 0.27$ & $1.87 \pm 0.21$ & $3.54 \pm 0.89$ & $1.57 \pm 0.40$ & $1.97 \pm 0.60$ & $1.88 \pm 0.32$ \\
\hline $\begin{array}{l}\text { n-3/n-6 } \\
\text { ratio }\end{array}$ & $0.86 \pm 0.04$ & $0.77 \pm 0.05$ & $0.82 \pm 0.02$ & $0.58 \pm 0.02$ & $2.62 \pm 0.29$ & $0.91 \pm 0.06$ & $1.78 \pm 0.19$ & $1.34 \pm 0.07$ & $1.86 \pm 0.22$ & $1.04 \pm 0.03$ \\
\hline $\begin{array}{l}\text { DHA/EPA } \\
\text { ratio }\end{array}$ & $2.55 \pm 0.34$ & $5.77 \pm 0.41$ & $5.25 \pm 0.50$ & $7.32 \pm 1.57$ & $2.50 \pm 0.30$ & $1.96 \pm 0.37$ & $2.17 \pm 0.33$ & $0.88 \pm 0.04$ & $1.51 \pm 0.10$ & $3.50 \pm 0.33$ \\
\hline
\end{tabular}

- $\quad$ Total lipid is expressed as mean weight $(\mathrm{g} / \mathrm{g}) \pm \mathrm{SD}$. Fatty acid values are expressed as $\%$ of total fatty acid methyl esters; mean \pm SD.

- $\quad$ EPA: Eicosapentaenoic acid; DHA: Docosahexaenoic acid; NMC: National Mariculture Centre.

The total SFAs value was higher in wild fish than farmed fish and the difference was statistically significant $(\mathrm{P}<0.05)$ (Table 2 and 3 ). The excess consumption of SFAs can lead to various inflammatory disorders for consumers (Santos et al., 2013). Thus, substitution of dietary SFAs with MUFAs and PUFAs has been advocated to reduce the hazardous complications and improve human health (Baum et al., 2012). However, it is important to consider the specific SFAs that should be excluded and included in the diet since not all of them are equal in their effects (O'Neill $\boldsymbol{e t}$ al., 2015). For example, steric acid (C18:0) which was the highest SFAs presented in both groups of farmed and wild 
fish samples with no statistically difference (Table 3) has no adverse effect on health (FAO/WHO, 2008). In contrast, palmitic acid (C16:0) that had significantly higher concentration in farmed fish than wild (Table 3) should be taken in consideration as it is a possible factor that may increase the level of low-density lipoprotein (LDL) which is the bad cholesterol (FAO/WHO, 2008). Thus, the high amount of SFAs presented in wild fish species included in this study (Table 2 and 3 ) is not worrisome, while farmed fish is the group of fish that need to undergo for more control procedures. On the other hand, all local farmed fish showed almost a double amount of palmitic acid (C16:0) compared to imported farmed fish (Tables 2 and 4). Replacing or limiting that specific SFAs (C16:0) in their diet may have positive effect on Bahraini consumers' health. In this context, raising conditions of farmed fish, specially their diet composition, could play an important role in fatty acids compositions of fish muscles (Fuentes et al., 2010; Rincón et al., 2016; Hossain and El-Dakour, 2019) and that farmed fish have the advantage of being raised under controlled conditions (Hossain, 2011; O'Neill et al., 2015).

\section{Monounsaturated fatty acids (MUFAs)}

The difference was significant between farmed and wild fish in the total amount of MUFAs, in which it was higher in wild than farmed fish (Table 3). The level of C18:1 n9, the highest among all MUFAs and its high content, was reflected on the elevated level of total MUFAs for all wild fish (Table 2 and 3); forming a typical feature in many marine fish (Hossain, 2011; Hossain et al., 2012; Rincón et al., 2016).

\section{Polyunsaturated fatty acids (PUFAs)}

The dominancy of PUFAs on SFAs and MUFAs in all fish under examination (Tables 2 and 3) is highly valuable for fish consumption as human body does not produce these fatty acids thus, should be obtained from diet (Mardani et al., 2016). Although a diet high in PUFAs can be beneficial to consumers, yet not all high PUFAs diets are equally in their benefit unless both n-3 PUFAs and n-6 PUFAs are taken into consideration (FAO/WHO, 2008).

\section{The n-3 and n-6 PUFAs profiles}

Generally, wild and farmed fish were comparable $(\mathrm{P}>0.05)$ in their $\mathrm{n}-3$ PUFAs profile (Table 3). This result confirmed the fact of fish importance as a unique and major source of n-3 PUFAs in human nutrition (Abbas and Jamilah, 2009; Tocher, 2015). However, the further evaluation performed for Sobaity Seabream (the only fish that had both farmed and wild samples from the Kingdom of Bahrain) showed that wild Sobaity 
Seabream had the significantly higher amount of total n-3 PUFAs than the farmed ones (Table 5). The increased amount of total n-3 PUFAs in wild fish compared to the farmed fish was explained by marine fish diet including small fish and crustacean; in other words, PUFAs content is mainly in the form of n-3 PUFAs (Hossain, 2011).

Table 3: Total lipid and fatty acids composition of farmed and wild fish samples in which the covariate

\begin{tabular}{|c|c|c|c|c|}
\hline & $\begin{array}{c}\text { Farmed Fish } \\
(\text { F })\end{array}$ & $\begin{array}{l}\text { Wild Fish } \\
\text { (W) }\end{array}$ & $\begin{array}{c}(F-W) \\
\Delta \text { Change (CI 95\%) }\end{array}$ & $\begin{array}{c}\text { P-Value } \\
\text { (sig.*) }\end{array}$ \\
\hline Total Lipid (g/g) & $0.18 \pm 0.01$ & $0.18 \pm 0.01$ & $-0.01(-0.02 ; 0.01)$ & 0.464 \\
\hline \multicolumn{5}{|l|}{ Fatty acids (\%) } \\
\hline SFAs & $23.40 \pm 0.14$ & $26.84 \pm 0.14$ & $-3.44(-3.83 ;-3.06)$ & $.000 *$ \\
\hline C16:0 & $4.04 \pm 0.18$ & $1.85 \pm 0.17$ & $2.19(1.56 ; 2.82)$ & $.000 *$ \\
\hline C18:0 & $22.32 \pm 0.67$ & $22.04 \pm 0.65$ & $0.29(-2.67 ; 2.64)$ & .811 \\
\hline UFAs & $67.53 \pm 0.19$ & $56.15 \pm 0.19$ & $11.39(10.49 ; 11.93)$ & $.000 *$ \\
\hline MUFAs & $14.59 \pm 0.11$ & $16.41 \pm 0.11$ & $-1.82(-2.11 ;-1.52)$ & $.000 *$ \\
\hline C16:1 n7 & $6.92 \pm 0.33$ & $3.33 \pm 0.32$ & $3.60(2.42 ; 4.77)$ & $.000 *$ \\
\hline C18:1 n9 & $5.49 \pm 0.32$ & $8.33 \pm 0.31$ & $-2.84(-3.94 ;-1.73)$ & $.000 *$ \\
\hline C20:1 n9 & $1.55 \pm 0.16$ & $0.77 \pm 0.16$ & $0.78(-0.23 ; 1.35)$ & $.006^{*}$ \\
\hline C22:1 n11 & $1.77 \pm 0.23$ & $2.75 \pm 0.22$ & $-0.97(-1.77 ;-0.181)$ & $.017 *$ \\
\hline PUFAs & $52.94 \pm 0.19$ & $39.74 \pm 0.19$ & $13.20(12.68 ; 13.72)$ & $.000 *$ \\
\hline n-6 & $28.62 \pm 0.10$ & $15.83 \pm 0.10$ & $12.79(12.53 ; 13.06)$ & $.000 *$ \\
\hline C18:2 n6 & $22.67 \pm 0.96$ & $14.81 \pm 0.93$ & $7.86(4.48 ; 11.24)$ & $.000 *$ \\
\hline C18:3 n6 & $2.89 \pm 0.11$ & $2.68 \pm 0.10$ & $0.22(-0.15 ; 0.57)$ & .245 \\
\hline C22:4 n6 & $1.11 \pm 0.08$ & $0.62 \pm 0.08$ & $0.48(0.19 ; 0.78)$ & $.001 *$ \\
\hline n-3 & $24.32 \pm 0.17$ & $23.91 \pm 0.17$ & $0.41(-0.07 ; 0.90)$ & .095 \\
\hline C18:3 n3 & $9.61 \pm 0.70$ & $4.55 \pm 0.68$ & $5.07(-2.61 ; 7.53)$ & $.000 *$ \\
\hline C18:4 n3 & $0.88 \pm 0.15$ & $0.99 \pm 0.15$ & $-0.11(-0.69 ; 0.43)$ & .695 \\
\hline C20:5 n3 (EPA) & $2.69 \pm 0.42$ & $6.09 \pm 0.41$ & $-3.41(-4.86 ;-1.95)$ & $.000 *$ \\
\hline C22:6 n3 (DHA) & $9.13 \pm 0.77$ & $10.44 \pm 0.75$ & $-1.31(-4.01 ; 1.39)$ & .341 \\
\hline $\mathrm{C} 22: 5 \mathrm{n} 3$ & $2.15 \pm 0.13$ & $1.65 \pm 0.13$ & $0.49(0.06 ; 0.94)$ & $.027 *$ \\
\hline n-3/n-6 ratio & $0.90 \pm 0.02$ & $1.56 \pm 0.02$ & $-0.70(-0.74 ;-0.65)$ & $.000 *$ \\
\hline DHA/EPA ratio & $4.29 \pm 0.07$ & $2.09 \pm 0.07$ & $2.20(2.00 ; 2.40)$ & $.000 *$ \\
\hline
\end{tabular}

- $\quad$ Total lipid is expressed as mean weight $(\mathrm{g} / \mathrm{g}) \pm$ SD. Fatty acid values are expressed as $\%$ of total fatty acid methyl esters; mean \pm SD.

- EPA: Eicosapentaenoic acid; DHA: Docosahexaenoic acid.

- $\quad *$ Statistically significant at $\mathrm{P}<0.05$. 
Table 4: The fatty acids composition of imported and NMC farmed Gilthead Seabream fish samples.

\begin{tabular}{|c|c|c|c|c|}
\hline & $\begin{array}{c}\text { Gilthead Seabream } \\
\text { (Imported) }\end{array}$ & $\begin{array}{c}\text { Gilthead Seabream } \\
\text { (NMC) }\end{array}$ & $\begin{array}{c}\text { (Imported-NMC) } \\
\Delta \text { Change (CI 95\%) }\end{array}$ & $\begin{array}{l}\text { P-Value } \\
\text { (sig.*) }\end{array}$ \\
\hline Total Lipid (g/g) & $0.23 \pm 0.01$ & $0.16 \pm 0.01$ & $0.07(0.03 ; 0.10)$ & $.000 *$ \\
\hline \multicolumn{5}{|l|}{ Fatty acids (\%) } \\
\hline SFAs & $16.43 \pm 0.26$ & $24.91 \pm 0.26$ & $-8.48(-9.26 ;-7.70)$ & $.000 *$ \\
\hline C16:0 & $2.33 \pm 0.08$ & $4.20 \pm 0.08$ & $-1.86(-2.09 ;-1.62)$ & $.000 *$ \\
\hline C18:0 & $14.10 \pm 0.20$ & $20.73 \pm 0.20$ & $-6.63(-7.22 ;-6.03)$ & $.000 *$ \\
\hline UFAs & $75.67 \pm 0.36$ & $65.50 \pm 0.36$ & $10.18(9.12 ; 11.24)$ & $.000 *$ \\
\hline MUFAs & $12.06 \pm 0.10$ & $16.83 \pm 0.10$ & $-4.77(-5.07 ;-4.46)$ & $.000 *$ \\
\hline C16:1n7 & $5.14 \pm 0.10$ & $8.22 \pm 0.10$ & $-3.08(-3.40 ;-2.759)$ & $.000 *$ \\
\hline C20:1n9 & $2.36 \pm 0.06$ & $0.63 \pm 0.06$ & $1.73(-1.56 ;-1.90)$ & $.000 *$ \\
\hline C18:1n9 & $3.25 \pm 0.07$ & $4.12 \pm 0.07$ & $-0.86(-1.08 ;-0.65)$ & $.000 *$ \\
\hline C22:1n11 & $1.31 \pm 0.06$ & $3.86 \pm 0.06$ & $-2.56(-2.73 ;-2.39)$ & $.000 *$ \\
\hline PUFAs & $63.61 \pm 0.34$ & $48.66 \pm 0.34$ & $14.95(13.95 ; 14.96)$ & $.000 *$ \\
\hline n-6 & $34.26 \pm 0.24$ & $27.49 \pm 0.24$ & $6.77(6.07 ; 7.48)$ & $.000 *$ \\
\hline C18:2n6 & $31.56 \pm 0.23$ & $23.97 \pm 0.23$ & $7.59(6.89 ; 8.28)$ & $.000 *$ \\
\hline C18:3n6 & $2.54 \pm 0.02$ & $3.20 \pm 0.02$ & $-0.66(-0.74 ;-0.59)$ & $.000 *$ \\
\hline C22:4n6 & $0.17 \pm 0.01$ & $0.32 \pm 0.01$ & $-0.15(-0.18 ;-0.12)$ & $.000 *$ \\
\hline $\mathbf{n - 3}$ & $29.35 \pm 0.33$ & $21.17 \pm 0.33$ & $8.18(7.21 ; 9.15)$ & $.000 *$ \\
\hline C18:3n3 & $17.81 \pm 0.11$ & $11.12 \pm 0.11$ & $6.69(6.36 ; 7.03)$ & $.000 *$ \\
\hline C18:4n3 & $2.06 \pm 0.03$ & $0.79 \pm 0.03$ & $1.27(1.19 ; 1.34)$ & $.000 *$ \\
\hline C20:5n3 (EPA) & $2.22 \pm 0.05$ & $1.07 \pm 0.05$ & $1.14(0.99 ; 1.288)$ & $.000 *$ \\
\hline C22:6n3 (DHA) & $5.631 \pm 0.22$ & $6.19 \pm 0.22$ & $-0.56(-1.21 ;-0.92)$ & $.000 *$ \\
\hline $\mathrm{C} 22: 5 n 3$ & $1.63 \pm 0.06$ & $1.99 \pm 0.06$ & $-0.36(-0.54 ;-0.19)$ & $.000 *$ \\
\hline n-3/n-6 ratio & $0.86 \pm 0.01$ & $0.77 \pm 0.01$ & $0.08(0.45 ; 0.13)$ & $.000 *$ \\
\hline DHA/EPA ratio & $2.55 \pm 0.12$ & $5.77 \pm 0.12$ & $-3.22(-3.57 ;-2.87)$ & $.000 *$ \\
\hline
\end{tabular}

- $\quad$ Total lipid is expressed as mean weight $(\mathrm{g} / \mathrm{g}) \pm$ SD. Fatty acid values are expressed as $\%$ of total fatty acid methyl esters; mean \pm SD.

- $\quad$ EPA: Eicosapentaenoic acid; DHA: Docosahexaenoic acid; NMC: National Mariculture Centre.

- $\quad *$ Statistically significant at $\mathrm{P}<0.05$.

The condition of increased total n-6 PUFAs concentration in farmed fish $(\mathrm{P}<0.05)$ compared to wild under the study (Table 3 and 5) was reported by other studies related to the type of farmed fish diet (Alasalvar et al., 2002; Fuentes et al., 2010; Hossain, 2011; Hossain et al., 2012; Rincón et al., 2016). The dominancy of linoleic acid (C18:2 n6) among n-6 series in farmed fish (Table 3) is probably related to the exsistance of this fatty acid in the oftenly used plant oils in farmed fish feed that accumulates largely unchanged (Alasalvar et al., 2002; Fuentes et al., 2010; Rincón et al., 2016; Hossain, 2011; Lenas et al., 2011; Amoussou et al., 2019). Therefore, the proper choice of dietary lipid would allow the fatty acids composition of farmed fish to provide the beneficial 
health aspects to meet the consumers' demands (Alasalvar et al., 2002; Amoussou et al., 2019).

There was difference between the local and imported farmed Gilthead Seabream regarding the total n-3 PUFAs in which imported fish showed statistically higher amount of $n-6$ and n-3 PUFAs than the local farmed from NMC (Table 4). The most possible reason for that superiority is probably the content of nutrients in farmed fish feed (Amoussou et al., 2019). Although the current study did not provide detailed information about farmed fish diet, it is obvious that each groups had a dissimilar diet, which leads to intergroup variation in fatty acid composition (O'Neill et al., 2015; Begum et al., 2019).

In Bahrain and other countries, fish (wild and farmed) have been identified as the primary source of n-3 fatty acids, that contain considerable high n-3 PUFAs concentrations that far exceed their n-6 PUFAs (Al-Arrayed et al., 1999; Abbas and Jamilah, 2009; Fuentes et al., 2010; Musaiger and Drsquo, 2011; Usydus et al., 2011; Hossain, 2011; O'Neill et al., 2015). In the current study, common feature was noticeable for all wild fish species (except for Greasy Grouper) in which they showed higher total n-3 PUFAs than their total n-6 PUFAs concentrations (Table 2). However, the above finding was reversed for farmed fish as their total n-6 PUFAs concentration exceeded their total n-3 PUFAs, because all farmed fish showed higher total n-6 PUFAs concentration than n-3 PUFAs (Table 2). The increased n-6 PUFAs amount in farmed fish (including the local kinds) reduces its nutritional value. This is because the metabolic products of both n-3 and n-6 PUFAs result in different and almost opposite physiological effects (Balk and Lichtenstein, 2017; Kones and Rumana, 2017).

In the current study, wild Greasy Grouper was the only fish that showed different trend, it had lower amount of total n-3 PUFAs than its total n-6 PUFAs similarly to other farmed fish samples (Table 2). That exceptionality can be due to many factors including the age of fish, gender, diet, pregnancy period, metabolism, reproduction state, season of fishing and the water temperature as well (O'Neill et al., 2015; Mardani et al., 2016; Kouroupakis et al., 2019). 
Table 5: The fatty acids composition of wild and local farmed Sobaity Seabream fish samples.

\begin{tabular}{|c|c|c|c|c|}
\hline & $\begin{array}{c}\text { Sobaity Seabream } \\
\text { (Wild) }\end{array}$ & $\begin{array}{c}\text { Sobaity Seabream } \\
\text { (NMC) }\end{array}$ & $\begin{array}{c}\text { (Wild-NMC) } \\
\Delta \text { Change (CI 95\%) }\end{array}$ & $\begin{array}{l}\text { P-Value } \\
\text { (sig.*) }\end{array}$ \\
\hline Total Lipid (g/g) & $0.11 \pm 0.01$ & $0.13 \pm 0.01$ & $-0.01(-0.04 ; 0.01)$ & .256 \\
\hline \multicolumn{5}{|l|}{ Fatty acids $(\%)$} \\
\hline SFA & $26.02 \pm 0.21$ & $30.31 \pm 0.21$ & $-4.29(-4.91 ;-3.67)$ & $.000 *$ \\
\hline C16:0 & $2.87 \pm 0.09$ & $4.27 \pm 0.09$ & $-1.40(-1.74 ;-1.07)$ & $.000^{*}$ \\
\hline C18:0 & $23.15 \pm 0.17$ & $26.04 \pm 0.17$ & $-2.89(-3.51 ;-2.27)$ & $.000^{*}$ \\
\hline UFAs & $48.62 \pm 0.49$ & $60.89 \pm 0.49$ & $-12.28(-13.70 ;-10.86)$ & $.000 *$ \\
\hline MUFAs & $14.53 \pm 0.23$ & $15.29 \pm 0.23$ & $-0.76(-1.43 ;-0.09)$ & $.027 *$ \\
\hline C16:1 n7 & $4.01 \pm 0.13$ & $6.31 \pm 0.13$ & $-2.30(-2.78 ;-1.82)$ & $.000^{*}$ \\
\hline C18:1 n9 & $7.35 \pm 0.17$ & $5.62 \pm 0.17$ & $1.73(1.12 ; 2.35)$ & $.000 *$ \\
\hline C20:1 n9 & $0.97 \pm 0.04$ & $0.58 \pm 0.04$ & $2.38(0.23 ; 0.54)$ & $.000 *$ \\
\hline C22:1 n11 & $2.20 \pm 0.08$ & $2.78 \pm 0.08$ & $-0.58(-0.88 ;-0.28)$ & $.000 *$ \\
\hline PUFAs & $34.09 \pm 0.38$ & $45.60 \pm 0.38$ & $-11.52(-12.62 ;-10.41)$ & $.000 *$ \\
\hline n-6 & $14.59 \pm 0.16$ & $28.77 \pm 0.16$ & $-14.18(-14.65 ; 13.71)$ & $.000 *$ \\
\hline C18:2 n6 & $11.24 \pm 0.13$ & $25.91 \pm 0.13$ & $-14.67(-15.12 ;-14.22)$ & $.000 *$ \\
\hline C18:3 n6 & $2.83 \pm 0.06$ & $2.63 \pm 0.06$ & $0.20(-0.02 ; 0.42)$ & .081 \\
\hline C22:4 n6 & $0.52 \pm 0.04$ & $0.22 \pm 0.04$ & $0.29(0.14 ; 0.45)$ & $.000 *$ \\
\hline n-3 & $19.50 \pm 0.30$ & $16.84 \pm 0.30$ & $2.66(1.80 ; 3.53)$ & $.000 *$ \\
\hline C18:3 n3 & $2.15 \pm 0.14$ & $9.33 \pm 0.14$ & $-7.18(-7.69 ;-6.68)$ & $.000 *$ \\
\hline C18:4 n3 & $0.64 \pm 0.03$ & $0.50 \pm 0.03$ & $0.14(0.05 ; 0.24)$ & $.002 *$ \\
\hline C20:5 n3 (EPA) & $8.06 \pm 0.13$ & $0.71 \pm 0.13$ & $7.34(6.87 ; 7.82)$ & $.000^{*}$ \\
\hline C22:6 n3 (DHA) & $7.08 \pm 0.14$ & $5.09 \pm 0.14$ & $1.99(1.47 ; 2.52)$ & $.000^{*}$ \\
\hline C22:5 n3 & $1.57 \pm 0.12$ & $1.20 \pm 0.12$ & $0.36(-0.05 ; 0.78)$ & .101 \\
\hline n-3/n-6 ratio & $1.34 \pm 0.02$ & $0.59 \pm 0.02$ & $0.75(0.71 ; 0.80)$ & $.000 *$ \\
\hline DHA/EPA ratio & $0.88 \pm 0.29$ & $7.32 \pm 0.29$ & $-6.44(-7.29 ;-5.59)$ & $.000 *$ \\
\hline
\end{tabular}

- $\quad$ Total lipid is expressed as mean weight $(\mathrm{g} / \mathrm{g}) \pm$ SD. Fatty acid values are expressed as \% of total fatty acid methyl esters; mean \pm SD.

- $\quad$ EPA: Eicosapentaenoic acid; DHA: Docosahexaenoic acid; NMC: National Mariculture Centre.

- $\quad$ *Statistically significant at $\mathrm{P}<0.05$.

The n-3/n-6 ratio

Numerous studies (Alasalvar et al., 2002; Mnari et al., 2007; Fuentes et al., 2010; Hossain, 2011; Lenas et al., 2011; Usydus et al., 2011; Hossain et al., 2012; O'Neill et al., 2015; Rincón et al., 2016; Begum et al., 2019; Hossain and El-Dakour, 2019) have promoted and used the $n-3 / n-6$ ratio and some of those studies (Usydus et al., 2011; Hossain et al., 2012; O'Neill et al., 2015; Begum et al., 2019) mentioned the suggested optimal n-3/n-6 ratio for good human health that should be 1:5 (0.2). However, those recommendations have been undergone to further studies as FAO/WHO (2008) stated that there is no recommended ratio for the n-3 to n- 6 fatty acids since they are consumed according to the established recommendations in the report. If the $n-3 / n-6$ 
theory become further advocated to be true in the future, then all the fish species (wild and farmed) in the current study would show higher ratios of $n-3 / n-6$ than the optimal ratio (0.2) as shown in Table 2. Consequently, all commonly consumed (wild and farmed) fish in Bahrain, that were selected in this study, promote human health and are nutritionally beneficial (Simopoulos, 2006; Hossain et al., 2012; O'Neill et al., 2015).

The results in the present study agreed with many other studies on other fish species that reported higher $\mathrm{n}-3 / \mathrm{n}-6$ ratio in wild fish than farmed counter types as the ratio was significantly higher in wild fish comparing to farmed sampled fish (Table 3) (Alasalvar et al., 2002; Fuentes et al., 2010; Hossain, 2011; Lenas et al., 2011; Usydus et al., 2011; O'Neill et al., 2015; Amoussou et al., 2019). It was reported that the location in which fish are caught is the main determinant of $n-3 / n-6$ ratio because it determines the composition of available diet in fish environments (Mnari et al., 2007; Hossain, 2011; Mardani et al., 2016; O'Neill et al., 2015; Kouroupakis et al., 2019). These findings showed that marine environment (the Arabian Gulf) is providing a fair source of n-3 PUFAs rich food (Al-Arrayed et al., 1999; Musaiger and Drsquo, 2011).

\section{The EPA and DHA values}

Humans are poor convertor to EPA and DHA, thus all AA, EPA and DHA must be obtained from the diet for good health and normal development (Simopoulos, 2006; Lenas et al., 2011; O'Neill et al., 2015; Rincón et al., 2016). Fish, in general, contain EPA and DHA; however their concentrations may vary between fish species and within the same species due to various environmental conditions (Freije, 2009). Moreover, wild fish contain higher levels of EPA and DHA than farmed fish (Alasalvar et al., 2002; Fuentes et al., 2010; Hossain, 2011; Lenas et al., 2011; Usydus et al., 2011; O'Neill et al., 2015; Amoussou et al., 2019). The current study showed comparable results to what was reported, in which wild fish samples were significantly higher in EPA and marginally higher in DHA value comparing to farmed (Table 3). The current findings revealed that all wild commonly consumed fish included in the study (except for wild Greasy Grouper) can offer higher amounts of EPA and DHA complexes for consumers compared to farmed fish as part of a regular well-balanced diet. However, wild fish ranking due to their content of n-3 PUFAs (high n-3/n-6 ratio and high EPA and DHA) were as follow: Doublebar Bream (Faskar) followed by Spangled Emperor (Sha'ree) and Rabbitfish (Saffy), Sobaity Seabream (Sobaity), Spanish Mackeral (Chana'ad), and Greasy Grouper (Hamoor), which was the least as shown in Table 2.

\section{CONCLUSION}

It can be concluded that, all the selected fish samples (wild and farmed) from Bahrain markets for this study are nutritionally beneficial for consumers because they showed higher ratios of n-3/n-6 than the suggested optimal ratio (0.2). However, all wild sampled fish (except for Greasy Grouper) are potentially healthier because they had 
higher n-3/n-6 ratios and can offer greater amounts of EPA and DHA complexes for consumers as part of a regular well-balanced diet. Among wild fish samples, the top three richest fish in n-3 PUFAs (highest n-3/n-6 ratio and highest in EPA and DHA content) that can be the favourite choice for residents of the Kingdom of Bahrain to promote health are: Doublebar Bream (Faskar), Spangled Emperor (Sha'ree), and then Rabbitfish (Saffy). In contrast, the deficit in n-3 PUFAs content of farmed fish that lowered their n-3/n-6 ratio (when compared to the wild fish) accounted for reduction in their nutritional quality. This, in return, may have resulted from manufactured feed that usually contain low quality lipids and could be harmful for consumers health.

\section{ACKNOWLEDGEMENT}

This study was supported and financially funded by the Department of Biology, College of Science, University of Bahrain.

\section{REFERENCES}

Abbas, K. A.; Mohamed, A., and Jamilah, B. (2009). Fatty acids in fish and beef and their nutritional values: A review. Journal of Food, Agriculture and Environment, 7(4): 37-42.

Al-Arrayed, F. H.; Al Maskati, H. A. and Abdullah, F. J. (1999). n3-polyunsaturated Fat Acid Content of Some Edible Fish from Bahrain Waters. Estuarine, Coastal and Shelf Science, 49: 109-114.

Alasalvar, C.; Tylor, K. D. A.; Zubcov, E.; Shahidi, F. and Alexis, M. (2002). Differentiation of cultured and wild seabass (Dicentrarchus labrax): total lipid content, fatty acid and trace mineral composition. Food Chemistry, 79: 145-150.

Amoussou, N.; Marengo, M.; Durieux, E. D. H.; Douny, C.; Scippo, M. L. and Gobert, S. (2019). Trace Elements and Fatty Acid Profile of Argyrosomus regius (Asso, 1801) from Mediterranean Aquaculture. Biological Trace Element Research, 1-11. doi: 10.1007/s12011-019-01925-X

Association of Official Analytical Chemists. (1990). Official Methods of Analysis: Changes in Official Methods of Analysis Made at the Annual Meeting. Supplement (Vol. 15). Association of Official Analytical Chemists. Retrieved from: https://law.resource.org/pub/us/cfr/ibr/002/aoac.methods.1.1990.pdf

Balk, E. M. and Lichtenstein, A. H. (2017). Omega-3 fatty acids and cardiovascular disease: summary of the 2016 Agency of Healthcare Research and Quality Evidence Review. Nutrients, 9(8) : 865.

Baum, S. J.; Kris-Etherton, P. M.; Willett, W. C.; Lichtenstein, A. H.; Rudel, L. L.; Maki, K. C. and Block, R. C. (2012). Fatty acids in cardiovascular health and disease: a comprehensive update. Journal of Clinical Lipidology, 6(3) : 216-234.

Begum, M.; Khan, S.; Bhowmik, S.; Lisa, S. A.; Juliana, F. M. and Hossain, M. S. (2019). Fatty Acid Composition of Hilsa (Tenualosa ilisha) Fish Muscle from Different Locations in Bangladesh. Thai Journal of Agricultural Science, 52(3): 172-179. 
Bligh, E. G. and Dyer, W. J. (1959). A rapid method of total lipid extraction and purification. Canadian Journal of Biochemistry and Physiology, 37(8): 911-917. Retrieved from: https://www.nrcresearchpress.com/doi/abs/10.1139/y59-099\#.Xreqj0QzaM8

Campbell, B. and Pauly, D. (2013). Mariculture: a global analysis of production trends since 1950. Marine Policy, 39: 94-100.

Food and Agriculture Organization of the United Nation. (2012). Report of the Workshop on the Social and Economic Aspects of Fisheries in the Recofi Region. FAO fisheries and agriculture report no. 1015. Retrieved from: www.fao.org/family-farming/detail/en/c/292883/

Food and Agriculture Organization of the United Nation. (2015). National Aquaculture Sector Overview: Bahrain. FOA. Fisheries and Aquaculture Department. Retrieved from: http://www.fao.org/fishery/countrysector/naso_bahrain/en

Food and Agriculture Organization. (2008). Interim Summary of Conclusions and Dietary Recommendations on Total Fat \& Fatty Acids. From the Joint FAO/WHO Expert Consultation on Fats and Fatty Acids in Human Nutrition, World Health Organization HQ, Geneva, 10-14. Retrieved from: https://www.who.int/nutrition/topics/FFA interim recommendations/en/

Freije, A. (2009). Fatty acid profile of the erythrocyte membranes of healthy Bahraini citizens in comparison with coronary heart disease patients. Journal of Oleo Science, 58(7): 379-388.

Freije, A. and Awadh, M. (2009). Total and methylmercury intake associated with fish consumption in Bahrain. Water and Environment Journal, 23(2), 155-164.

Fuentes, A.; Fernández-Segovia, I.; Serra, J. A. and Barat, J. M. (2010). Comparison of wild and cultured sea bass (Dicentrarchus labrax) quality. Food Chemistry, 119(4): 1514-1518.

Hossain, M. A. (2011). Fish as source of n-3 polyunsaturated fatty acids (PUFAs), which one is betterfarmed or wild. Advance Journal of Food Science and Technology, 3(6): 455-466.

Hossain, M. A.; Al-Abdul-Elah, K. and El-Dakour, S. (2019). Improvement of nutritional quality of cultured sobaity sea bream, Sparidentex hasta (Valenciennes) muscle by preharvest feeding of finisher feeds. Journal of Applied Ichthyology, 35(6): 1197-1208.

Hossain, M. A.; Al-Abdul-Elah, K. and Yaseen, S. B. (2019). Seasonal variations in proximate and fatty acid composition of sobaity sea bream (Sparidentex hasta) in Kuwait waters. Journal of the Marine Biological Association of the United Kingdom, 99(4): 991-998.

Hossain, M. A.; Almatar, S. M.; Al-Abdul-Elah, K. M. and Yaseen, S. B. (2012). Comparison of proximate composition and fatty acid profiles in cultured and wild marine fishes in Kuwait. Journal of Applied Aquaculture, 24(3): 199-209.

Kones, R. and Rumana, U. (2017). Omega-3 polyunsaturated fatty acids: new evidence supports cardiovascular benefits. Journal of Public Health and Emergency, 1(4): Retrieved from: http://jphe.amegroups.com/article/view/3860 
Kouroupakis, E.; Grigorakis, K.; Vardali, S.; Ilia, V.; Batjakas, I. and Kotzamanis, I. Y. (2019). Evaluation of the fillet quality of wild-caught white sea bream (Diplodus sargus L.) and brown meagre (Sciaena umbra L.) captured from the Aegean Sea. Mediterranean Marine Science, 20(2): 373-379.

Lenas, D.; Chatziantoniou, S.; Nathanailides, C. and Triantafillou, D. (2011). Comparison of wild and farmed sea bass (Dicentrarchus labrax L) lipid quality. Procedia Food Science, 1: 1139-1145.

Mardani, M.; Asadi-Samani, M.; Rezapour, S. and Rezapour, P. (2016). Evaluation of bred fish and seawater fish in terms of nutritional value, and heavy metals. Journal of Chemical and Pharmaceutical Sciences, 9(3): 1277-1283.

Mnari, A.; Bouhlel, I.; Chraief, I.; Hammami, M.; Romdhane, M. S.; El Cafsi, M. and Chaouch, A. (2007). Fatty acids in muscles and liver of Tunisian wild and farmed gilthead sea bream, Sparus aurata. Food Chemistry, 100(4): 1393-1397.

Musaiger, A. O. and Drsquo, R. (2011). Fatty acid profile of raw and cooked fish consumed in Bahrain. African Journal of Food Science, 5(4): 213-218.

Niencheski, L. F.; Windom, H. L.; Baraj, B.; Wells, D. and Smith, R. (2001). Mercury in fish from Patos and Mirim lagoons, Southern Brazil. Marine Pollution Bulletin, 42(12): 1403-1406.

O'Neill, B.; Le Roux, A. and Hoffman, L. C. (2015). Comparative study of the nutritional composition of wild versus farmed yellowtail (Seriola lalandi). Aquaculture, 448: 169-175.

Onyia, L. U.; Michael, K. S.; Manu, J. M. and Sabo, M. (2013). Comparison of nutrient values of wild and cultured Heterobranchus bidorsalis and Clarias gariepinus. Nigerian Journal of Fisheries and Aquaculture, 1: 7-12.

Ozogul, Y.; Şimşek, A.; BalIkçI, E. and Kenar, M. (2012). The effects of extraction methods on the contents of fatty acids, especially EPA and DHA in marine lipids. International Journal of Food Sciences and Nutrition, 63(3): 326-331.

Rincón, L.; Castro, P. L.; Álvarez, B.; Hernández, M. D.; Álvarez, A.; Claret, A. and Ginés, R. (2016). Differences in proximal and fatty acid profiles, sensory characteristics, texture, colour and muscle cellularity between wild and farmed blackspot seabream (Pagellus bogaraveo). Aquaculture, 451: 195-204.

Santos, S.; Oliveira, A. and Lopes, C. (2013). Systematic review of saturated fatty acids on inflammation and circulating levels of adipokines. Nutrition Research, 33(9): 687-695.

Simopoulos, A. P. (2006). Evolutionary aspects of diet, the omega-6/omega-3 ratio and genetic variation: nutritional implications for chronic diseases. Biomedicine \& Pharmacotherapy, 60(9): 502-507.

Tocher, D. R. (2015). Omega-3 long-chain polyunsaturated fatty acids and aquaculture in perspective. Aquaculture, 449: 94-107.

Usydus, Z.; Szlinder-Richert, J.; Adamczyk, M. and Szatkowska, U. (2011). Marine and farmed fish in the Polish market: Comparison of the nutritional value. Food Chemistry, 126(1): 78-84. 